\title{
KARAKTERISTIK SIFAT KIMIAWI DAN ORGANOLEPTIK FRUIT LEATHER DENGAN VARIASI PERBANDINGAN PEPAYA (Carica papaya L.) DAN DAUN KELOR (Moringa oleifera $L$.
}

\author{
Atik Puji Lestari'), Agustina Intan Niken Tari2), Novian Wely Asmoro3) \\ 1,2,3) Fakultas Pertanian, Program StudiTeknologi Hasil Pertanian, Universitas Veteran Bangun \\ Nusantara, Jl. Letjend S. Humardani No 1 Jombor Sukoharjo, Telp (0271) 593156, \\ email:atik.pujilestari12@gmail.com \\ 2)Koresponding author; email: intanniken@gmail.com
}

\begin{abstract}
Abstrak
Fruit leather adalah suatu produk olahan buah yang dikonsumsi sebagai kudapan (snack food). Fruit leather terbuat dari satu jenis atau campuran beberapa macam buah yang dihancurkan dan dikeringkan menjadi lembaran tipis. Pada penelitian ini dipilih buah pepaya dan daun kelor sebagai bahan baku pembuatan fruit leather. Tujuan dari penelitian adalah mengetahui formulasi fruit leather buah pepaya dan daun kelor yang baik, karakteristik kimia dan sifat organoleptik. Metode penelitian menggunakan Rancangan Acak Lengkap (RAL) dengan 1 faktor yang terdiri dari 5 variasi formula, setiap perlakuan diulang 3 kali dan 2 ulangan analisis atau duplo, sehingga diperoleh 30 unit percobaan. Data yang diperoleh dianalisis secara statistik menggunakan Analysis of Variance (ANOVA) dan Duncan Multiple Range Test (DMRT) pada taraf 5\%. Hasil penelitian ini menunjukkan bahwa variasi fruit leather pepaya dan tepung daun kelor berpengaruh nyata terhadap kadar air, kadar abu, vitamin C, aktioksidan, organoleptik rasa dan overall tetapi tidak berpengaruh nyata terhadap organoleptik aroma.Pemilihan formulasi terbaik fruit leather pepaya dan tepung daun kelor didapatkan pada perlakuan F1 (99 gr pepaya + 1 gr tepung daun kelor) dengan kadar airsebesar 18,72\%, kadar abusebesar 2,43\%, vitamin Csebesar 0,28 mg/gr, antioksidan sebesar 20,07\%, organoleptik rasa sebesar 3,23\%; aroma sebesar 2,57 \% dan overall sebesar 3,27 \%.
\end{abstract}

Kata kunci : Daun kelor, Fruit leather,Pepaya, Sifat kimia, Sifat Organoleptik

\begin{abstract}
Fruit leather is a processed fruit product that is consumed as a snack (snack food). Fruit leather is made from one type or mixture of several kinds of fruit that is crushed and dried into thin sheets. In this study papaya and moringa leaves were selected as the raw material for making fruit leather. The purpose of this research is to find out the good formulation of papaya fruit leaves and Moringa leaves, chemical characteristics and organoleptic properties. The research method used a Completely Randomized Design (CRD) with 1 factor consisting of 5 variations of the formula, each treatment is repeated 3 times and 2 repetitions of analysis or duplo, so that 30 units of the experiment are obtained. The data obtained were statistically analyzed using Analysis of Variance (ANOVA) and Duncan Multiple Range Test (DMRT) at 5\% level. The results of this study showed that the variation of papaya fruit leather and moringa leaf flour significantly affected water content, ash content, vitamin $C$, antioxidants, organoleptic taste and overall but did not significantly affect organoleptic aroma. Selection of the best formulation of papaya fruit leather and moringa leaf flour was obtained in F1 treatment (99 gr papaya $+1 \mathrm{gr}$ moringa leaf flour) with a water content of $18,72 \%$, ash content of $2,43 \%$, vitamin C of $0,28 \mathrm{mg} / \mathrm{gr}$, antioxidants by $20,07 \%$, organoleptic flavors by $3,23 \%$; aroma of $2,57 \%$ and overall of $3,27 \%$.
\end{abstract}

Keywords : Chemical properties, Fruit leather, Moringa leaves, Organoleptic properties, Papaya

\section{PENDAHULUAN}

Fruit leather merupakan suatu produk olahan buah yang dikonsumsi sebagai kudapan (snack food). Fruit leather terbuat dari satu jenis atau campuran beberapa macam buah yang dihancurkan dan dikeringkan menjadi lembaran tipis dengan ketebalan 2-3 mm, mempunyai konsistensi, dan rasa khas tergantung dari buah yang digunakan (Primawidya, 2017). Fruit leather yang diharapkan warnanya sesuai dengan bahan baku yang digunakan, tekstur sedikit liat dan kompak, serta bersifat plastis sehingga dapat digulung atau tidak mudah patah. Fruit leather dapat dibuat dari 
beberapa buah dengan flavor yang kuat dan kandungan pektin yang tinggi (Praseptiangga, 2016).

Penelitian ini akan dibuat fruit leather dari campuran buah pepaya dan daun kelor. Pemilihan buah pepaya merupakan salah satu buah yang mudah tumbuh didaerah beriklim tropis dan sangat mudah diperoleh. Buah pepaya memiliki rasa manis, aroma yang khas dan dagingnya berwarna kuning kemerahan. Khasiat buah ini sangat banyak karena kandungan senyawa fitokimianya, seperti vitamin $A$, vitamin $C$, dan mineral. Adapun daun kelor yang dipilih adalah daun kelor yang berwarna hijau. Daun kelor mudah diperoleh didaerah tropis seperti Indonesia.

Buah pepaya dan tepung daun kelor memiliki kandungan pektin yang rendah sehingga memerlukan penambahan pembentuk gel agar menghasilkan tekstur yang diinginkan. Salah satu bahan pembentuk gel digunakan adalah karagenan. Menurut Zhaki (2018) Karagenan merupakan senyawa polisakarida dan galaktosa hasil ekstraksi rumput laut yang bersifat hidrofilik. Karagenan yang digunakan adalah jenis kappa karagenan, karena kappa karagenan dapat membentuk gel yang kuat dibandingkan jenis iota dan lambda. Karagenan memiliki kelebihan yaitu mampu membentuk gel dan sebagai pengental, larut dalam air panas, gel berwarna transparan, membentuk tekstur yang baik pada fruit leather dan harganya lebih ekonomis.

Belum diketahui formula yang tepat pada fruit leather pepaya dan tepung daun kelor, sehingga perlu dilakukan penelitian. Informasi sifat kimia dan organoleptik fruit leather pepaya dan tepung daun kelor juga belum diketahui.

\section{BAHAN DAN METODE}

\section{Bahan}

Bahan yang digunakan dalam penelitian ini yaitu sampel fruit leather pepaya dan daun kelor, aquades, amilum $1 \%, \mathrm{KIO}_{3}, \mathrm{I}_{2}$, etanol 95\%, DPPH.

\section{Metode}

\section{Tahapan Persiapan}

Tahap pertama yang dilakukan dalam penelitian adalah pembuatan tepung daun kelor dan pembuatan bubur pepaya. Diagram alir pembuatan tepung daun kelor dan bubur pepayadapat dilihat pada Gambar 1 dan Gambar 2.

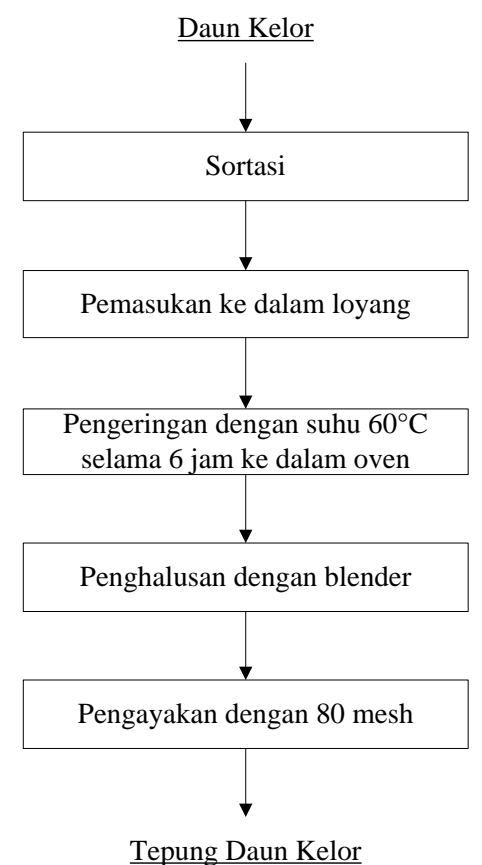

Gambar 1 Pembuatan Tepung Daun Kelor

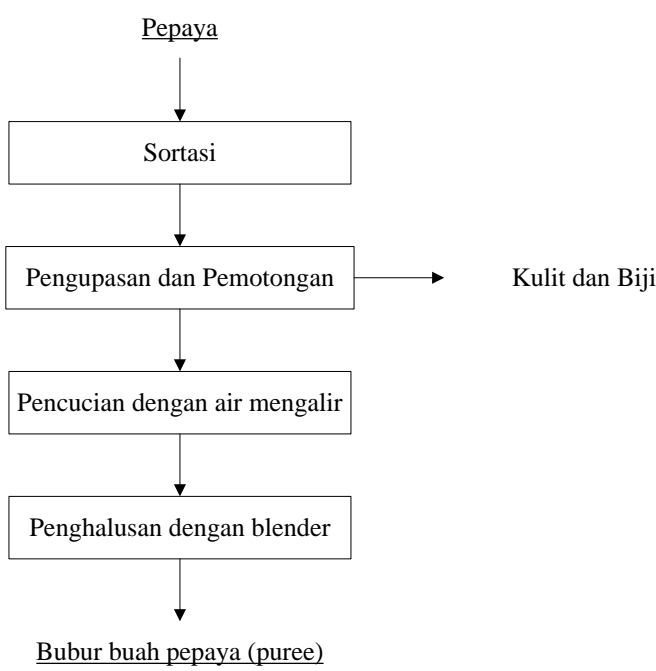

Gambar 2. Pembuatan Bubur Pepaya 


\section{Penelitian Utama}

Proses pembuatan fruit leather pepaya dan tepung daun kelor menggunakan 5 perlakuan yaitu F0 (100 gr pepaya $+0 \mathrm{gr}$ tepung daun kelor); F1 (99 gr pepaya $+1 \mathrm{gr}$ tepung daun kelor); F2 (98 gr pepaya +2 gr tepung daun kelor); F3 (97 gr pepaya $+3 \mathrm{gr}$ tepung daun kelor); F4 (96 gr pepaya $+4 \mathrm{gr}$ tepung daun kelor). Diagram alir pembuatan fruit leather dapat dilihat pada Gambar 3

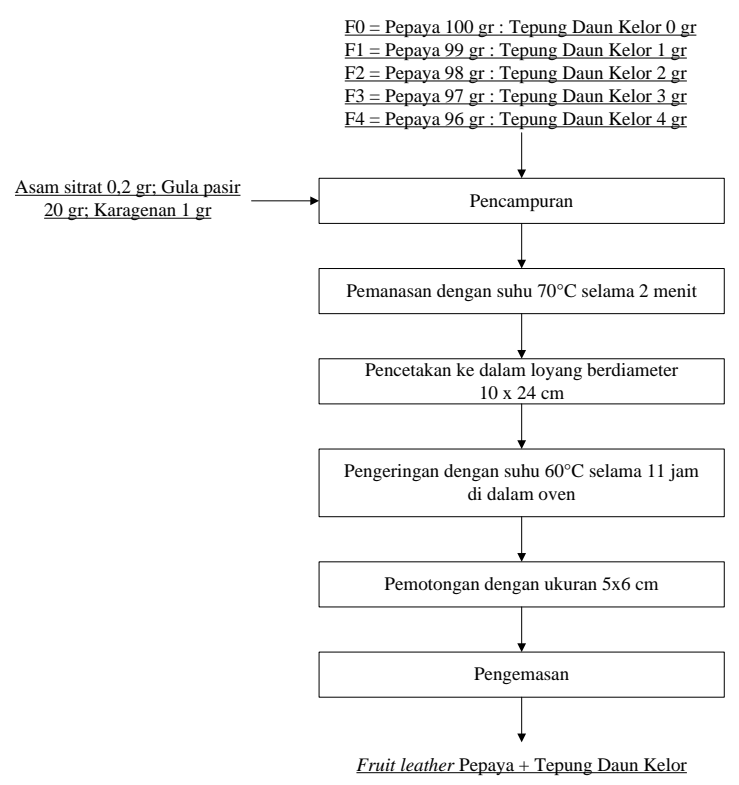

Gambar 3. Pembuatan Fruit Leather Pepaya dan Tepung Daun Kelor

Penelitian ini menganalisis sifat kimia yaitu kadar air, kadar abu, vitamin C, antioksidan dan organoleptik (rasa, aroma dan overall) menggunakan Rancangan Acak Lengkap (RAL), dengan 1 faktor perlakuan yaitu formula fruit leather $(F)$ dengan 5 perlakuan. Formulasi tersebut masing-masing perlakuan dibuat ulangan 3 kali. Data yang diperoleh dari hasil penelitian kemudian dianalisis menggunakan Analysis of Variance (ANOVA) melalui SPSS. Jika terdapat perbedaan atau beda nyata maka dilanjutkan dengan uji menggunakan Duncan Multiple Range Test (DMRT) dengan taraf signifikansi 0,05 .

\section{HASIL DAN PEMBAHASAN}

Fruit leather pepaya dan tepung daun kelor merupakan produk makanan ringan berbentuk lembaran tipis yang terbuat dari bubur pepaya, tepung daun kelor, karagenan, asam sitrat dan gula pasir dapat dilihat pada gambar 4
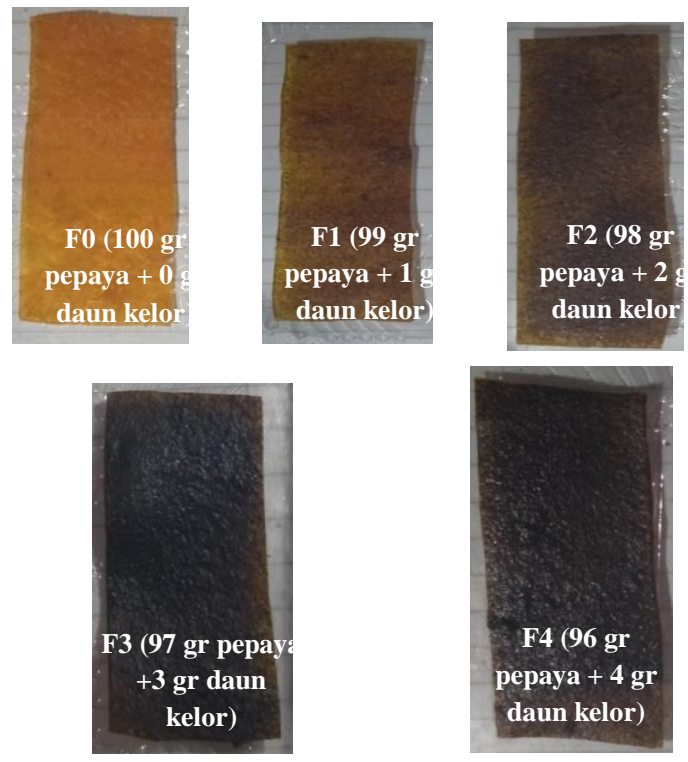

\section{Gambar 4 fruit leather pepaya dan tepung daun kelor}

\section{Kadar Air}

Kadar air merupakan salah satu parameter yang penting untuk dianalisis karena banyaknya air yang terkandung dalam suatu produk menentukan aseptibilitas, kesegaran dan daya tahan bahan itu. Air juga merupakan komponen penting dalam bahan makanan karena air dapat mempengaruhi kenampakan, tekstur dan cita rasa makanan (Murdiah dan Putri, 2015).

Pada penelitian ini menggunakan penentuan kadar air cara pengeringan (Thermogravimetri). Prinsipnya yaitu menguapkan air yang ada dalam bahan sampai berat konstan yang berarti semua air sudah diuapkan. Cara ini relatif mudah dan murah (Sudarmadji dkk, 2010).

Hasil analisis sidik ragam menunjukkan bahwa perbandingan bubur pepaya dan tepung daun kelor memberikan pengaruh yang berbeda nyata terhadap kadar air fruit leather $(\mathrm{p}<0,05)$. Semakin banyak tepung daun 
kelor ditambahkan hasilnya akan mengalami peningkatan. Nilaifruit leather pepaya dan tepung daun kelor (\%) berkisar antara $18,72 \%$ sampai dengan $21,23 \%$. Hal ini dapat dilihat pada Gambar 5.

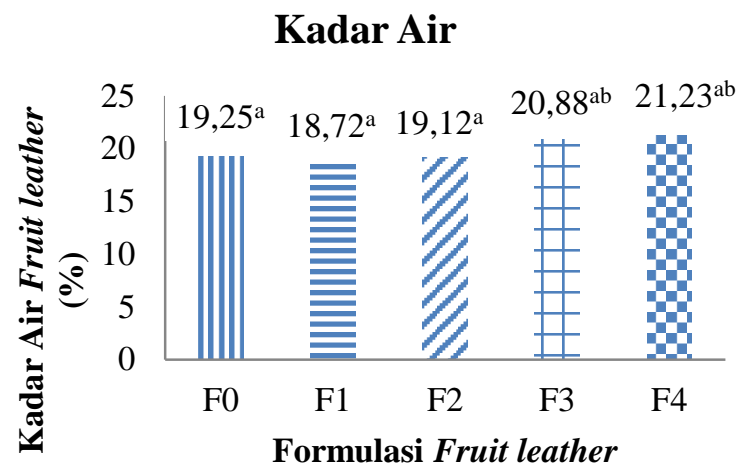

Keterangan : Huruf kecil yang berbeda pada histogram menunjukkan perbedaan yang signifikan $(p<0,05)$.

Gambar 5. Pengaruh penambahan tepung daun kelor terhadap kadar air fruit leather pepaya dan tepung daun kelor.

Gambar 5. Menunjukkan bahwa kadar air yang dihasilkan pada fruit leather pepaya dan tepung daun kelor pada formulasi F0 sebesar 19,25\%; F1 sebesar 18,72\%; F2 sebesar 19,12\%; F3 sebesar 20,88\% dan F4 sebesar $21,23 \%$.

Pada penelitian ini kadar air fruit leather pepaya dan tepung daun kelor mengalami peningkatan dikarenakan tepung daun kelor memiliki kadar air sebesar 9,57\% maka semakin banyak tepung daun kelor ditambahkan hasilnya akan mengalami peningkatan.Penelitian ini sejalan dengan penelitian Dewi (2019) Hasil kadar air pada pembuatan cookies dengan penambahan tepung daun kelor $40 \%, 50 \%$ dan $60 \%$ mengalami peningkatan yaitu 11,92\%; $13,57 \%$, dan 12,61\%.Nilai kadar air fruit leather pada perlakuan penambahan tepung daun kelor mengalami kenaikan dikarenakan pada penambahan tepung daun kelor tersebut menjadikan air pada bubur pepaya terikat pada tepung daun kelor sehingga tidak banyakmengalami penurunan kadar air pada proses pemanasannya, selain itu konsentrasi penambahan tepung daun kelor antar perlakuan kecil perbedaan konsentrasinya.

\section{Kadar Abu}

Kadar abu merupakan bahan-bahan anorganik yang tidak terbakar dalam proses pengabuan, sedangkan bahan-bahan organik terbakar. Kadar abu dalam suatu bahan pangan sangat mempengaruhi sifat dari bahan pangan tersebut. Kandungan abu dan komposisinya bergantung pada macam bahan dan cara pengabuan yang digunakan. Kandungan abu dari suatu bahan menunjukkan kadar mineral dalam bahan tersebut (Mardiah dan Putri, 2015).

Pada penelitian ini menggunakan penentuan kadar abu secara langsung (Cara kering) yaitu dengan mengoksidasikan semua zat organik pada suhu tinggi yaitu sekitar 500$600^{\circ} \mathrm{C}$ dan kemudian melakukan penimbangan zat yang tertinggal setelah proses pembakaran tersebut. Sampel yang akan diabukan ditimbang sejumlah tertentu tergantung macam bahannya (Sudarmadji dkk, 2010).

Perhitungan kadar abu yaitu :

$$
\% \mathrm{Abu}=\frac{\text { Berat Abu }}{\text { Berat Sampel }} \times 100 \%
$$

Hasil analisis sidik ragam menunjukkan bahwa perbandingan bubur pepaya dan tepung daun kelor memberikan pengaruh yang berbeda nyata terhadap kadar abufruit leather $(\mathrm{p}<0,05)$. Semakin banyak tepung daun kelor ditambahkan hasilnya akan mengalami peningkatan. Nilaifruit leather pepaya dan tepung daun kelor (\%) berkisar antara 2,19\% sampai dengan $2,59 \%$. Hal ini dapat dilihat pada Gambar 6 . 


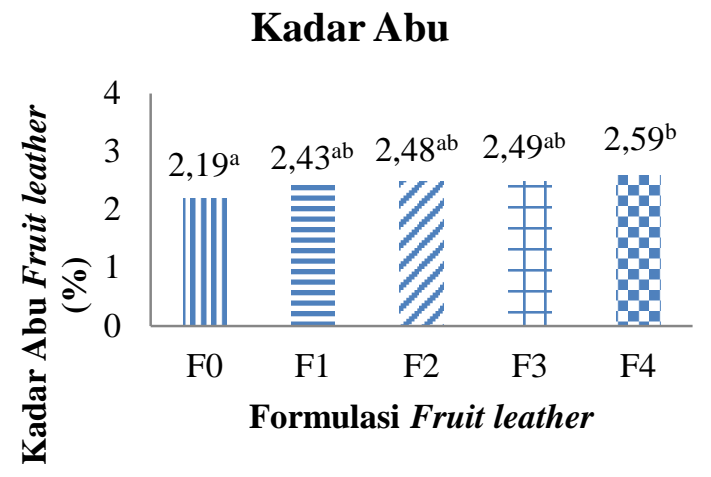

Keterangan : Huruf kecil yang berbeda pada histogram menunjukkan perbedaan yang signifikan $(p<0,05)$.

Gambar 6. Pengaruh penambahan tepung daun kelor terhadap kadar abu fruit leather pepaya dan tepung daun kelor

Gambar 6. Menunjukkan bahwa kadar abu yang dihasilkan pada fruit leather pepaya dan tepung daun kelor pada formulasi F0 sebesar 2,19\%; F1 sebesar 2,43\%; F2 sebesar 2,48\%; F3 sebesar 2,49\% dan F4 sebesar $2,59 \%$. Pada penelitian ini kadar abu mengalami peningkatan dikarenakan konsentrasi tepung daun kelor menyebabkan kadar abu meningkat dibandingkan penambahan tepung daun kelor $0 \%$. Peningkatan kadar abu ini disebabkan karena tingginya kadar abu atau kandungan mineral (zat organik) pada tepung daun kelor yaitu sebesar 10,1808\% sehingga apabila persentase tepung daun kelor yang digunakan banyak maka kadar abu pada produk juga meningkat (Sinaga dkk, 2019).

\section{Vitamin C}

Vitamin C merupakan salah satu nilai gizi yang penting pada berbagai varietas buah-buahan dan sayuran. Vitamin $\mathrm{C}$ atau asam askorbat mempunyai berat molekul 178 dengan rumus molekul $\mathrm{C}_{6} \mathrm{H}_{8} \mathrm{O}_{6}$. Dalam bentuk kristal tidak berwarna, titik cair $190-192^{\circ} \mathrm{C}$. Bersifat larut dalam air sedikit larut dalam aseton atau alkohol yang mempunyai berat molekul rendah (Sudarmadji dkk, 2010).

Pada penelitian ini menggunakan penentuan vitamin $\mathrm{C}$ dengan titrasi iodin. Hal ini berdasarkan sifat bahwa vitamin $\mathrm{C}$ dapat beraksi dengan iodin. Indikator yang dipakai adalah amilum. Akhir titrasi ditandai dengan terjadinya warna biru dari iod amilum. Perhitungan kadar vitamin $\mathrm{C}$ dengan standarisasi larutan iodin adalah tiap $1 \mathrm{ml}$ $0,01 \mathrm{~N}$ iodin ekuivalen dengan $0,88 \mathrm{mg}$ asam askorbat.

Perhitungan vitamin $\mathrm{C}$ yaitu :

$$
\begin{aligned}
& \text { Vitamin } C=\frac{\mathrm{a}(\mathrm{mg})}{\text { Berat Bahan }(\mathrm{gr})} \\
& \mathrm{a}(\mathrm{mg})=\frac{(\mathrm{ml} \times \mathrm{N}) \mathrm{KIO} 3 \times 0,88 \mathrm{mg} \times \text { pengenceran }}{0,1}
\end{aligned}
$$

(Sudarmadji, 2007).

Hasil analisis sidik ragam menunjukkan bahwa perbandingan bubur pepaya dan tepung daun kelor memberikan pengaruh yang berbeda nyata terhadap vitamin Cfruit leather $(p<0,05)$. Semakin banyak tepung daun kelor ditambahkan hasilnya akan mengalami peningkatan. Nilaifruit leather pepaya dan tepung daun kelor (\%) berkisar antara 0,28 $\mathrm{mg} / \mathrm{gr}$ sampai dengan $0,38 \mathrm{mg} / \mathrm{gr}$. Hal ini dapat dilihat pada Gambar 7.

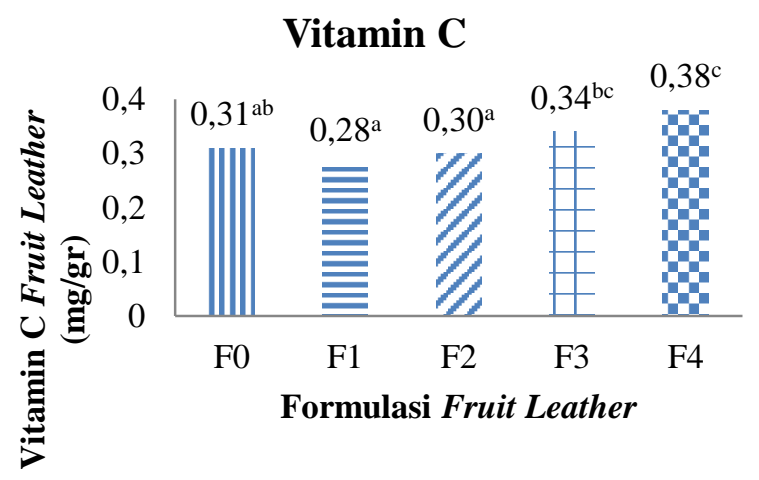

Keterangan : Huruf kecil yang berbeda pada histogram menunjukkan perbedaan yang signifikan $(p<0,05)$.

Gambar 7. Pengaruh penambahan tepung daun kelor terhadap vitamin Cfruit leather pepaya dan tepung daun kelor

Gambar 7. Menunjukkan bahwa vitamin C yang dihasilkan pada fruit leather pepaya dan tepung daun kelor pada formulasi F0 sebesar $0,31 \mathrm{mg} / \mathrm{gr} ; \mathrm{F} 1$ sebesar 0,28 $\mathrm{mg} / \mathrm{gr}$; F2 sebesar 0,30 $\mathrm{mg} / \mathrm{gr}$; F3 sebesar $0,34 \mathrm{mg} / \mathrm{gr}$ dan $\mathrm{F} 4$ sebesar $0,38 \mathrm{mg} / \mathrm{gr}$. 
Pada penelitian ini kadar vitamin C mengalami peningkatan dikarenakan kandungan vitamin $\mathrm{C}$ pada tepung daun kelor lebih tinggi dibandingkan dengan buah pepaya, semakin banyak jumlah tepung daun kelor yang digunakan dan semakin sedikit jumlah buah pepaya yang digunakan maka semakin tinggi vitamin $\mathrm{C}$ yang dihasilkan pada analisis kimia fruit leather (Puspitasari dkk, 2019). Penelitian ini sejalan dengan penelitian Suryanti (2017) Konsentrasi tepung daun kelor menyebabkan vitamin $\mathrm{C}$ meningkat dibandingkan penambahan tepung daun kelor $0 \%$. Hasil penelitian vitamin $\mathrm{C}$ dengan penambahan daun kelor yaitu $1,5 \mathrm{gr} ; 2 \mathrm{gr}$ dan $2,5 \mathrm{gr}$ pada pembuatan teh mengalami kenaikan sebesar $0,15 \% ; 0,27 \%$ dan $0,29 \%$

\section{Antioksidan}

Antioksidan merupakan senyawa yang dapat menghambat reaksi oksidasi, dengan mengikat radikal bebas dan molekul yang sangat reaktif. Akibatnnya, kerusakan sel dapat dihambat. Radikal bebas adalah suatu senyawa atau molekul yang mengandung satu atau lebih elektron tidak berpasangan pada orbital luarnya (Amin dkk, 2015).

Antioksidan memiliki kemampuan untuk menetralisir radikal bebas tanpa menjadi radikal bebas itu sendiri. Ketika antioksidan menetralkan radikal bebas dengan menerima atau menyumbangkan elektron, mereka tidak akan berubah menjadi radikal bebas dan tetap stabil (Najihudin dkk, 2017).

Pada penelitian ini dilakukan pengujian aktivitas antioksidan fruit leather pepaya dan tepung daun kelor dengan metode DPPH (2,2-diphenyl-1-picrylhydrazyI). Metode DPPH merupakan suatu metode untuk menentukan aktivitas antioksidan dalam sampel dengan melihat kemampuan dalam menangkal radikal bebas senyawa 2,2-diphenyl-1-picrylhydrazyl. Penggunaan DPPH sebagai metode ini mudah digunakan, mempunyai sensitifitas yang tingi dan dapat menganalisis bahan dalam jumlah yang besar dalam waktu yang singkat.
Perhitungan aktivitas antioksidan yaitu :

Antioksidan $\%=100 \times 1$
$\frac{\text { absorbansi sampel }}{\text { absorbansi kontrol }}$

Hasil analisis sidik ragam menunjukkan bahwa perbandingan bubur pepaya dan tepung daun kelor memberikan pengaruh yang berbeda nyata terhadap antioksidanfruit leather $(\mathrm{p}<0,05)$. Semakin banyak tepung daun kelor ditambahkan hasilnya akan mengalami peningkatan. Nilai fruit leather pepaya dan tepung daun kelor (\%) berkisar antara 16,06\% sampai dengan $29,86 \%$. Hal ini dapat dilihat pada Gambar 8.

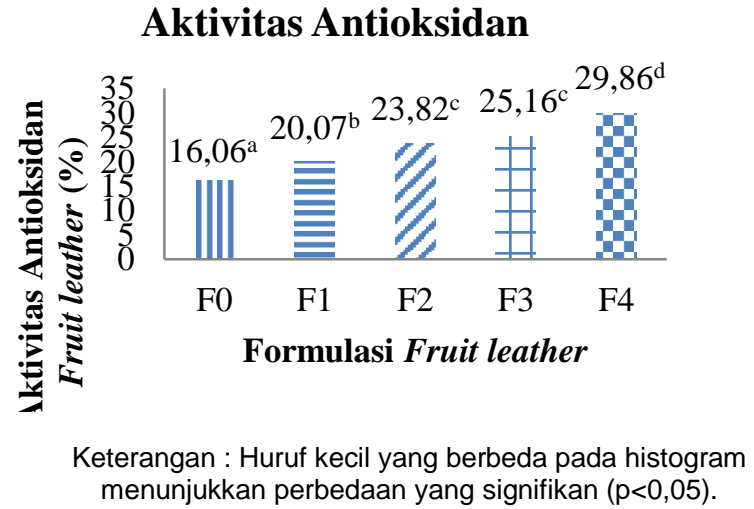

Gambar 8. Pengaruh penambahan tepung daun kelor terhadap aktivitas antioksidan fruit leather pepaya dan tepung daun kelor

Gambar 8. Menunjukkan bahwa aktivitas antioksidan yang dihasilkan pada fruit leather pepaya dan tepung daun kelor pada formulasi F0 sebesar 16,06\%; F1 sebesar $20,07 \%$; F2 sebesar 23,82\%; F3 sebesar $25,16 \%$ dan $\mathrm{F} 4$ sebesar $29,86 \%$.

Pada penelitian ini aktivitas antioksidan mengalami peningkatan. Kandungan aktivitas antioksidan pada tepung daun kelor lebih tinggi dibandingkan dengan buah pepaya, semakin banyak jumlah tepung daun kelor yang digunakan dan semakin sedikit jumlah buah pepaya yang digunakan maka semakin tinggi aktivitas antioksidan yang dihasilkan pada analisis kimia fruit leather (Puspitasari dkk, 2019). Penelitian ini sejalan dengan penelitian Sartina dkk (2018) Konsentrasi tepung daun kelor menyebabkan aktivitas antioksidan meningkat dibandingkan 
penambahan tepung daun kelor 0\%. Hasil penelitian penambahan daun kelor sebesar $5 \% ; 10 \%$ dan $15 \%$ terhadap aktivitas antioksidan chips sagu mengalami kenaikan, semakin banyak daun kelor yang ditambahkan maka aktivitas antioksidan meningkat.

\section{Uji Organoleptik}

Uji organoleptik dalam penelitian ini menggunakan pengujian tingkat kesukaan panelis dengan metode skoring. Uji kesukaan ranking adalah pengujian organoleptik yang melibatkan panelis untuk diminta menilai produk fruit leather pepaya dan tepung daun kelor dengan skala yang telah ditentukan dan dalam penilaian tidak diperbolehkan mencantumkan skala yang sama.

Panelis diminta untuk menilai produk fruit leather pepaya dan tepung daun kelor pada 5 skala hedonik. Skala nilai yang akan digunakan adalah 5 untuk sangat suka, 4 untuk suka, 3 untuk agak suka, 2 untuk kurang suka dan 1 untuk tidak suka. Pada uji organoleptik fruit leather pepaya dan tepung daun kelor menggunakan panelis tidak terlatih sebanyak 30 panelis. Hasil uji kesukaan ranking dianalisis menggunakan ANOVA (Analysis of Variance) dengan uji lanjut beda nyata menggunakan Duncan Multiple Range Test pada tingkat signifikansi 0,05. Uji organoleptik terhadap fruit leather yang dihasilkan meliputi rasa, aroma dan overall.

\section{Rasa}

Rasa merupakan salah satu parameter mutu yang dapat ditangkap oleh indera perasa. Rasa juga memegang peranan penting dalam menentukan suatu produk diterima atau tidak oleh konsumen (Darmawan, 2017).

Hasil analisis sidik ragam menunjukkan bahwa perbandingan bubur pepaya dan tepung daun kelor memberikan pengaruh yang berbeda nyata terhadap organoleptik rasafruit leather $(\mathrm{p}<0,05)$. Berdasarkan hasil uji rasa fruit leather pepaya dan tepung daun kelor, bahwa semakin besar penambahan tepung daun kelor maka rasa fruit leather pepaya dan tepung daun kelor yang dihasilkan semakin terasa tepung daun kelor dan ada rasa pahitnya pada perlakuan F4 dengan nilai 2,57. Hal ini diduga seiring meningkatnya jumlah tepung daun kelor yang ditambahkan, maka akan menyebabkan terjadinya peningkatan intensitas rasa tepung daun kelor. Hal ini dapat dilihat pada Gambar 9.

\section{Diagram sensoris rasa fruit leather pepaya dan tepung daun kelor}

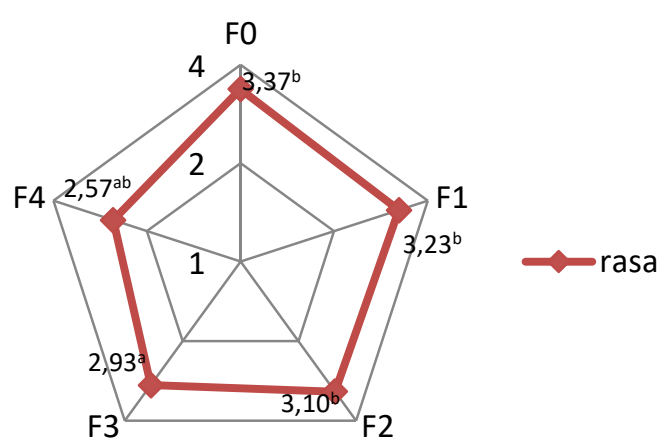

Keterangan : Huruf kecil yang berbeda pada histogram menunjukkan perbedaan yang signifikan $(p<0,05)$.

Gambar 9. Diagram sensoris rasa fruit leather pepaya dan tepung daun kelor

Gambar 9. Menunjukkan bahwa oragnoleptik rasa yang dihasilkan pada fruit leather pepaya dan tepung daun kelor berdasarkan uji lanjut beda nyata (Duncan) diketahui bahwa penambahan tepung daun kelor F3 (tepung daun kelor 3\%) dengan nilai $2,93 \%$ dan F4 (tepung daun kelor $4 \%$ ) dengan nilai $2,57 \%$ berbeda nyata dengan $\mathrm{F} 2$ (tepung daun kelor $2 \%$ ) dengan nilai 3,10\%, F1 (tepung daun kelor 1\%)dengan nilai 3,23\% dan F0 (tepungdaun kelor $0 \%$ ) dengan nilai $3,37 \%$. Penambahan tepung daun kelor mempengaruhi rasa pada fruit leatherpepaya dan tepung daun kelor karena sifat tepung daun kelor memberikan rasa tertinggal (aftertaste) sehingga rasa manis fruit leather menurun. Penambahan tepung daun kelor 
yang semakin tinggi menyebabkan mutu rasa dari fruit leather menurun.

\section{Aroma}

Aroma merupakan sesuatu yang dapat diamati dengan indra pembau, aroma dianggap sangat penting karena dengan cepat dapat menghasilkan penelitian terhadap produk tentang diterima atau ditolaknya suatu produk (Ruchdiansyah dkk, 2016).

Hasil analisis sidik ragam menunjukkan bahwa perbandingan bubur pepaya dan tepung daun kelor memberikan pengaruh yang tidak berbeda nyata terhadap organoleptik aromafruit leather $(p>0,05)$. Hal ini dapat dilihat pada Gambar 10.

\section{Diagram sensoris aroma fruit leather pepaya dan tepung daun kelor}
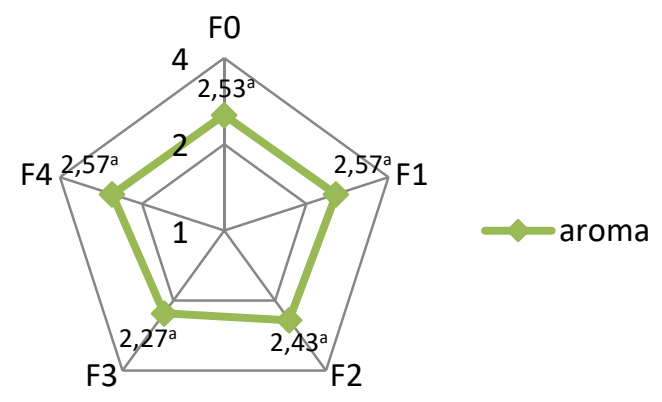

Keterangan : Huruf kecil yang tidak berbeda pada histogram menunjukkan perbedaan yang tidak signifikan $(p>0,05)$.

Gambar 10. Diagram sensoris aroma fruit leather pepaya dan tepung daun kelor

Gambar 10. Menunjukkan bahwa oragnoleptik aroma yang dihasilkan pada fruit leather pepaya dan tepung daun kelorpada kelima perlakuan yaitu F0 (tepung daun kelor 0\%), F1 (tepung daun kelor 1\%), F2 (tepung daun kelor $2 \%$ ), F3 (tepung daun kelor 3\%), dan F4 (tepung daun kelor 4\%) tidak berbeda nyata terhadap mutu aroma fruit leather pepaya dan tepung daun kelor dengan nilai 2,$53 ; 2,57 ; 2,43 ; 2,27$ dan 2,57. Tepung daun kelor yang ditambahkan jumlahnya tidak signifikan dan tidak jauh berbeda sehingga penambahannya tidak mempengaruhi mutu aroma fruit leather pepaya dan tepung daun kelor.

\section{Overall}

Parameter keseluruhan (Overall) digunakan dalam uji hedonic untuk mengukur tingkat kesukaan panelis terhadap keseluruhan atribut yang ada pada produk (Augustyn dkk, 2017).

Hasil analisis sidik ragam menunjukkan bahwa perbandingan bubur pepaya dan tepung daun kelor memberikan pengaruh yang berbeda nyata terhadap organoleptik overallfruit leather $(\mathrm{p}<0,05)$. Hal ini dapat dilihat pada Gambar 11.

\section{Diagram sensoris overall fruit leather pepaya dan tepung daun kelor}

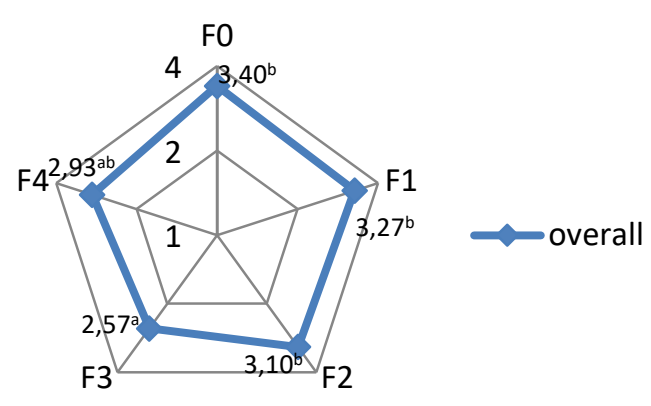

\footnotetext{
Keterangan : Huruf kecil yang berbeda pada histogram menunjukkan perbedaan yang signifikan $(p<0,05)$.
}

Gambar 11. Diagram sensoris overall fruit leather pepaya dan tepung daun kelor

Gambar 11. Menunjukkan bahwa penambahan tepung daun kelor F3 (tepung daun kelor 3\%) dan F4 (tepung daun kelor $4 \%$ ) berbeda nyata dengan F2 (tepung daun kelor 2\%), F1 (tepung daun kelor 1\%) dan F0 (tepung daun kelor $0 \%$ ). Nilai sensoris overall berturut-turut sebesar 3,40\%, 3,27\%, 3,10\%, $2,57 \%$ dan $2,93 \%$. Formula F1 mempunyai nilai yang tidak berbeda dengan kontrol. Penilaian tingkat kesukaan panelis terhadap overall pada fruit leather pepaya dan daun kelor dengan konsentrasi $1 \%$ mendapatkan 
nilai 3,27\% untuk tingkat kesukaan konsumen yang masih dapat diterima.

\section{Pemilihan Formulasi Terbaik}

Berdasarkan uji organoleptik terhadap fruit leather pepaya dan tepung daun kelor perlakuan F1 (99 gr pepaya + 1 gr tepung daun kelor) merupakan perlakuan terbaik. Hal tersebut dikarenakan perlakuan $\mathrm{F} 1$ lebih disukai oleh panelis dalam hal rasa sebesar $3,23 \%$, aroma sebesar $2,57 \%$ dan overall sebesar 3,27 \% dan didukung dengan kadar air sebesar 18,72 \%; kadar abu sebesar 2,43\%; vitamin C sebesar 20,07 mg/gr; Rasa $3,23 \%$; Aroma 2,57\% dan Overall 3,27\%

\section{SIMPULAN}

Pemilihan formulasi terbaik fruit leather pepaya dan tepung daun kelor didapatkan pada perlakuan F1 (99 gr pepaya +1 gr tepung daun kelor) dengan kadar airsebesar 18,72 \%, kadar abusebesar 2,43 \%, vitamin Csebesar 0,28 $\mathrm{mg} / \mathrm{gr}$, antioksidan sebesar 20,07 \%, organoleptik rasa sebesar 3,23\%; aroma sebesar $2,57 \%$ dan overall sebesar 3,27 $\%$.

\section{DAFTAR PUSTAKA}

Amin, A., Wunas J., Anin Y. M. (2015) Uji Aktivitas Antioksidan Ekstrak Etanol Klika Faloak dengan Metode DPPH. Jurnal Fitofarmaka Indonesia. 2 (2): 111-114.

Amin, A., Wunas J., Anin Y. M. (2015) Uji Aktivitas Antioksidan Ekstrak Etanol Klika Faloak dengan Metode DPPH. Jurnal Fitofarmaka Indonesia. 2 (2): 111-114.

Augustyn, G. H., H. C. D. Tuhumury dan M. Dahoklory. (2017) Pengaruh Penambahan Tepung Daun Kelor (Moringa oleifer) terhadap Karakteristik Organoleptik dan Kimia Biskuit Mocaf (Modified Cassava Flour). Jurnal Teknologi Pertanian. 6 (2): 52-58.

Darmawan, E. (2017) Daya Terima Konsumen terhadap Bakpao yang diperkaya Sifat
Fungsiol Serat dan Antioksidan Berbasis Daun Kelor (Moringa oleifer Lam). Jurnal Agrotech. 2 (1): 50-53.

Dewi, D. P. (2018). Subtitusi Tepung Daun Kelor (Moringa oleifera L.) pada Cookies terhadap Sifat Fisik, Sifat Organoleptik, Kadar Proksimat, dan Kadar Fe. Jurnal IImu Gizi Indonesia. 1 (2): 104-112.

Mardiah dan Putri, R. M. S. (2015) Kajian Karakteristik Fisiko Kimia dan Sensori Manisan Pidada dengan Konsentrasi Agar-agar Serbuk yang Berbeda. Jurnal Teknologi Pertanian. 4 (2): 8-17.

Megawati. (2019) Kajian Karakteristik Fisikokimia dan Sensoris Fruit Leather Pisang Kepok (Musa paradisiaca F.) dan Buah Naga Merah (Hylocereus polyrhizus) dengan Penambahan Karagenan. Skripsi. Fakultas PertanianPeternakan. Universitas Muhammadiyah Malang.

Najihudin, A., A. Chaerunisaa., A. Subarnas. (2017). Aktivitas Antioksidan Ekstrak dan Fraksi Kulit Batang Trengguli (Cassia fistula $L$ ) dengan Metode DPPH. Jurnal IJPST. 4 (2): 1-9.

Praseptiangga, D., T.P. Aviany., dan N.H.R. Parnanto. (2016) Pengaruh Penambahan Gum Arab terhadap Karakteristik Fisikokimia dan Sensoris Fruit Leather Nangka. Jurnal Teknologi Hasil Pertanian. 4 (1): 71-83.

Primawidya, N.F., Sheilla., F. Hamzah., dan Rahmayuni. (2017) Pemanfaatan Bubur Buah Jambu Biji Putih dan Bubur Buah Pepaya dalam Pembuatan Fruit Leather. Jom Faperta. 4 (2): 1-14.

Puspitasari, F. A., M. Karyantina dan Y. A. Widanti. (2019) Karakteristik Fruit Leather dengan Variasi Rasio Buah Naga Merah (Hylocereus polyrhizus) Pepaya (Carica papaya L.) dan Suhu Pengeringan. Jurnal Teknologi dan Industri Pangan. 4 (1): 7-14.

Ruchdiansyah, D., N. Novidahlia dan L. Amalia. (2016) Formulasi Kerupuk dengan Penambahan Daun Kelor (Moringa oleifer Lam). Jurnal Pertanian. 7 (2): 51-65.

Sartina., Ansharullah., S. Rejeki. (2018). Pengaruh Penambahan Daun Kelor 
Lestari, et al. 2020

Terhadap Aktivitas Antioksidan Chips Sagu. Jurnal Sains dan Teknologi Pangan. 3 (3): 1356-1367.

Sinaga, H., R. A. Purba dan M. Nurminah. (2019) Pengaruh Penambahan Tepung Daun Kelor (Moringa oleifer) dalam Pembuatan Kue Onde-Onde Ketawa menggunakan Tepung Mocaf. Jurnal JFLS. 3 (1): 29-37.

Sudarmadji, S., B. Haryono., dan Suhardi. (2007) Prosedur Analisa untuk Bahan Makanan dan Pertanian. Liberty.Yogyakarta.

Suryanti, Diyah. (2017). Uji Vitamin C dan Sifat Organoleptik Teh Daun Kelor Kombinasi Kulit Apel dengan Variasi Suhu Pengeringan. Skripsi. Fakultas Keguruan dan Ilmu Pendidikan. Universitas Muhammadiyah Surakarta.

Zhaki, M., N. Harun., dan F. Hamzah. (2018) Penambahan Berbagai Konsentrasi Karagenan terhadap Karakteristik Fruit Leather Pepaya. Jurnal JOM UR. 5 (2): 1-14 